Nigerian Journal of Physiological Sciences 24 (2): 107 - 107 @Physiological Society of Nigeria, 2009

Available online/abstracted at http://www.bioline.org.br/np; www.ajol.info/journals.njps; www.cas.org

\title{
HEXAMETHONIUM PRODUCES BOTH TWITCH AND TETANIC DEPRESSION WITHOUT FADE IN COMMON AFRICAN TOAD (Bufo regularis)
}

\author{
E. S. AJibola*, A. O. Adebayo, F. C. THOMAS, S. A. RAHMAN, A. M. \\ GBADEBO AND T. A. ODUNBAKU \\ College of Veterinary medicine, University of Agriculture, Abeokuta, Nigeria E-mail: \\ esajibola@yahoo.com
}

\begin{abstract}
Summary: The study was designed to investigate the nature of the cholinoceptors at the sciatic nervegastrocnemius muscle junction of the common African toad (Bufo regularis). Using myographic technique, the twitch properties of the sciatic-gastrocnemius muscle preparation of the common African toad was studied. Both the twitch height and peak tetanic height were measured as a percentage of control. Hexamethonium at a concentratration of $0.1 \mathrm{mM}$ significantly $(\mathrm{P}<0.05)$ reduced the mean twitch height from $2.62 \mathrm{~cm}$ to $1.0 \mathrm{~cm}$ and mean peak tetanic height from $5.38 \mathrm{~cm}$ to $4.32 \mathrm{~cm}$. Hexamethonium, however does not produce tetanic fade at the same concentration. We hypothesized that the cholinoceptors of the neuromuscular junction of the common African toad (Bufo regularis) resemble the developing synapse of African clawed toad (Xenopus laevis) and may contain muscarinic $\mathrm{M}_{1}$ autoreceptors at the pre juntional membrane.
\end{abstract}

Keywords: Hexamethonium, Tetanic fade, Bufo regularis, Cholinoceptors

\section{Introduction}

So much work has been done on hexamethonium, a non depolarizing blocker of both the mammalian end plate and ganglion. Hexamethonium blocks synaptic transmission in the superior cervical ganglion of the cat (Paton and Zaimis, 1951) and submandibular ganglion of the rat (Rang, 1982). In the anaesthetized cat, hexamethonium produces complete fade to zero tension in the absence of any twitch depression and with relatively little depression of peak tension (Bowman and Webb, 1976). Within the amphibian species, however, research work on the neuromuscular junction has tended to concentrate on the frog (Colquhoun and Sheridan, 1978; Diane and Humphrey, 1988; Adam et al, 1981.) with little or no work on toad, another member of the class.

At the frog's neuromuscular junction, it has been found that hexamethonium acts as a receptor antagonist rather than an ion channel blocker (Diane and Humphrey, 1988). A contrary finding to this was reported by (Adam et al, 1981) who found that hexamethonium is more likely to act as a channel blocker rather than a receptor antagonist. In this study, we investigated the nature of the cholinergic receptors at the neuromuscular junction of the common African toad (Bufo regularis) using the sciatic-gastrocnemius muscle preparation rather than the more popular sciatic-sartorius muscle preparation.

\section{Materials and method \\ Experimental Animals}

Toads of the Bufo regularis species weighing between 80-100grams were used for the experiment. They were randomly collected and maintained in the animal house on a $12 \mathrm{hrs}$ light/dark cycle. Animal handling and experiment were carried out according to guidelines given by the local ethics committee.

Sciatic Nerve- Gastrocnemius Muscle Preparation

The experiment was carried out in-vitro on the sciatic nerve-gastrocnemius muscle preparation. Isolation and removal of the preparation was according to the method of (MIT, 1999) The preparation was placed in a nerve-muscle chamber partially filled with frog's Ringer solution of the following composition: $\mathrm{NaCl}$, 98.5mM; KCl, 2.5mM; $\mathrm{NaH}_{2} \mathrm{PO}_{4} 1.9 \mathrm{mM}$; $\mathrm{NaHPO} 4,4.8 \mathrm{mM} ; \mathrm{CaCl}_{2}, 2.0 \mathrm{mM}$. The knee was pinned to the base of the chamber and the muscle was tied to the lever with a thread attached to the Achilles tendon. A test solution of $1 \mathrm{mM}$ hexamethonium (sigma, UK) was made in Ringer solution. Each of the preparation was exposed to the same drug concentration. Five 
milliliters of $1 \mathrm{mM}$ of hexamethonium was added to the tissue bath to make it up to the desired concentration. The drug was allowed a contact time of fifteen minutes (Imre et al, 1995).

\section{Nerve Stimulation and Recordings}

The ischiatic nerve is stimulated with a square wave pulse of $0.2 \mathrm{~ms}$ duration and at a voltage of 1.5 volts via an inbuilt stimulator of a universal kymograph (Harvard apparatus,UK). Single twitches were elicited at $1 \mathrm{H}_{\mathrm{Z}}$ and at drum speed of $625 \mathrm{~mm} / \mathrm{sec}$.and tetani at $30 \mathrm{H}_{\mathrm{Z}}$ for five seconds and at a speed of $2.5 \mathrm{~mm} / \mathrm{sec}$.Isometric myographic recordings were made. Twitch height depression and peak tetanic height depression were measured as a percentage of control. The tension produced at the beginning of the tetanic stimulation (a) was compared with that obtained at the end of tetanic stimulation (b) the ratio obtained $(\mathrm{R}=\mathrm{b} / \mathrm{a})$ is the tetanic fade (Silva et al, 1999).

Data were expressed as mean \pm Standard Deviation of mean. Mean values were compared using paired student $\mathrm{t}$ test. $\mathrm{P}<0.05$ was considered significant. A simple regression analysis was used to study the relationship between percentage twitch height depression and percentage peak tetanic height depression

\section{RESULT}

Table 1 clearly showed that the control twitch $(2.62 \pm 0.5)$ is significantly higher than the hexamethonium induced twitch $(1.0 \pm 0.7)$ at $\mathrm{P}<0.05$ level of significance. The table also showed that the control peak tetanic height $(5.38 \pm 0.7)$ is higher than that of hexamethonium induced peak tetanic height $(4.32 \pm 0.69)$

Figure 1 showed the scatter plot of the relationship between percentage twitch height depression and percentage peak tetanic height depression. Linear regression analysis of this data revealed a significant correlation between the two variables at $\mathrm{P}<0.05$. The correlation coefficient $r$ was found to be 0.527 . The regression model is represented by $\mathrm{Y}=0.12 \mathrm{x}$ +26.71 .

\section{DISCUSSION}

Contrary to the well established scientific report that hexamethonium induced complete fade of tetanic contraction while leaving the twitch unaffected.(Bowman and Webb, 1976;Gibb and Marshall, 1986;Gallacci and Oliveira, 1990), our current study has shown that hexamethonium produced both twitch height and peak tetanic height depression without fade in the common African toad (Bufo regularis).

Dependent Variable: \% PEAK TETANIC HEIGHT DEPRESSION

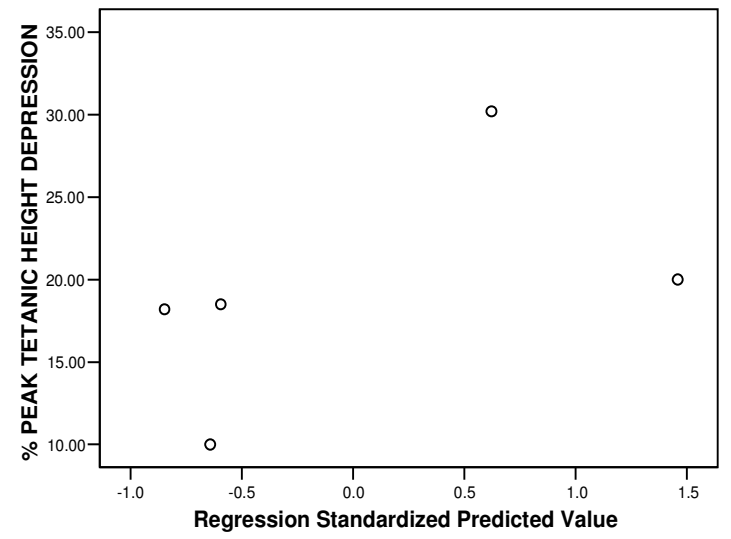

Fig. 1: A scatter plot of the percentage twitch height depression against percentage titanic height depression. $\mathrm{r}=0.527$ at $\mathrm{P}<0.05$.

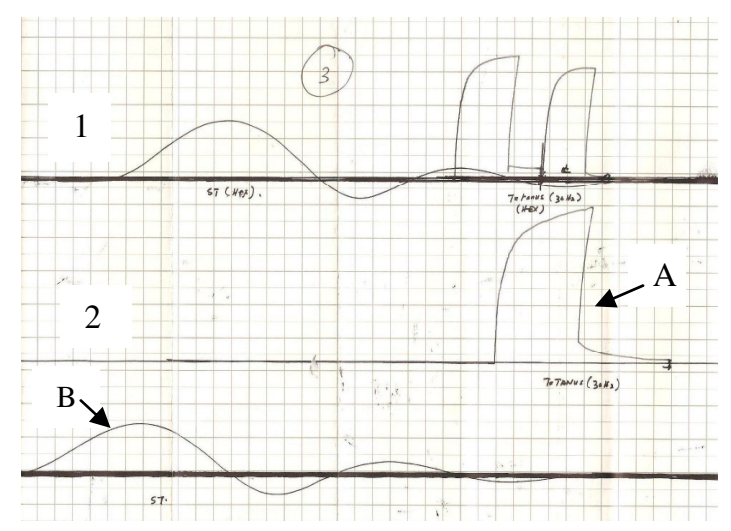

Fig. 2: Traces of the control (1) and hexamethonium - induced $(2 A \& B)$ Twitches and Tetani.

Table 1: Effect of hexamethonium on twitch height and peak tetanic height

\begin{tabular}{cccc}
\hline $\begin{array}{c}\text { Twitch } \\
\text { amplitude }(\mathrm{cm})\end{array}$ & Control & $\begin{array}{c}\text { Hexamethoni } \\
\text { um }\end{array}$ & P value \\
\hline $\begin{array}{c}\text { Pretetanic } \\
\text { twitch height }\end{array}$ & $\begin{array}{c}2.62 \\
\pm 0.5\end{array}$ & $1.0 \pm 0.7$ & $\mathrm{P}<0.05$ \\
\hline $\begin{array}{c}\text { Peak tetanic } \\
\text { twitch height }\end{array}$ & $\begin{array}{c}5.38 \\
\pm 0.71\end{array}$ & $4.32 \pm 0.69$ & $\mathrm{NIL}$ \\
\hline Values are mean $\pm \mathrm{SD}, \mathrm{n}=5$ & &
\end{tabular}


Synaptic cholinoceptors of African toad

Interestingly, we also saw a correlation between percentage peak height depression and percentage twitch height depression a finding which suggested that both effects could be mediated through the same receptor. Tetanic fade or Wendesky inhibition is the failure of a muscle to sustain tension during high frequency motor nerve stimulation in the presence of a non depolarizing neuromuscular blocking drug (Bowman, 1980).

Various mechanisms have been put forward to explain this phenomenon. Some authors are of the opinion that hexamethonium-induced fade is a consequence of the attenuation of the positive feedback process involved in the acetylcholine release at the prejunctional membrane of the junction (Bowman,1980; Gibb and Marshall, 1984;Miguel et al,2003) rather than a use dependent block of the open ion channel (Diane and Humphrey,1988;Gibb and Marshall,1986;Richard and John,1981,Rang and Rylett, 1984) in the post junctional membrane. Some other authors however argue that end plate potential rundown or tetanic fade reflects a complex (pre and postsynaptic) set of phenomena that may also depend on species and stimulating conditions.(Magleby et al, 1981).

Diversity in the nicotinic cholinergic receptor types is derived from the variability of genes encoding for receptor subunits and the different subunit combinations (Lukas et al 1999). Several lines of evidences indicate that neuronal and muscular nicotinic receptors present at the neuromuscular junction differ in pharmacological profile (Gibb and Marshall, 1984). Since the nature and molecular identity of the nicotinic receptors in the common African toad is not yet defined, many hypotheses that revolve around both presynaptic and postsynaptic mechanisms can be put forward to explain the phenomenon noticed in this particular study.

The effects hexamethonium on the neuromuscular junction of the toad is very similar to what has been reported for $\alpha$ bungarotoxin in the rat's isolated diaphragm (Miguel et al, 2003).At both neuromuscular junctions, hexamethonium caused twitch height depression and peak tetanic height depression without fade. $\alpha$ bungarotoxin is a known agonist of muscle type $\alpha_{1}$ and an antagonist of $\alpha_{7}$ prejunctional nicotinic cholinergic receptor(Dwoskin and Crooks,2001). Since treatment of Xenopus nerve and muscle cell culture, a developing synapse with $10 \mu \mathrm{M}$ hexamethonium has an antagonizing effect similar to that of $\alpha$ bungarotoxin, (Wen-Mei and Jiunn-Jiun, 1997) we postulate that nicotinic receptor profile of the common African toad is very much similar to that of the developing synapse of African clawed toad (Xenopus laevis).

A high frequency nerve evoked muscle stimulation coupled with a greater expression of $\alpha 3 \beta 2$ subunit of the presynaptic receptors could increase the safety margin of transmission at the neuromuscular junction and thus account for the result we got in this study. This is possible because blockade of the $\alpha 3 \beta 2$ subunit of the neuronal nicotinic cholinergic receptor which is known to mediate positive feedback release of acetylcholine causes fade in the rat isolated diaphragm (Gibb and Marshall, 1984).

Another possible hypothesis that could explain the result of our study is the likelihood of overexpression of the muscarinic $\mathrm{M}_{1}$ autoreceptors at the prejunctional membrane of the common African toad.We are of the opinion that since blockade of $M_{1}$ auto receptors in rat diaphragm results in twitch depression without fade, an observation that perfectly match our findings, then, there is a basis for comparing both neuromuscular junctions.

To address the many speculations and questions that have been raised in this study, future work in our laboratory will focus on understanding the molecular characteristics and electrophysiological properties of the neuromuscular junction of the common African toad (Bufo regularis).

\section{References}

Adam, D. J., Bevans, S. and Terrar, D. A (1991). Mode of hexamethonium action on acetyl choline receptor channels in frog skeletal muscle. Br. J. Pharmacol.102 (1):135-145.

Bowman, W. C (1980). Prejuntional and post junctional cholinoceptors at the neuromuscular junction. Anaesth. Analg. 59:935-943

Bowman W. C and Webb, S. N. (1976). Tetanic fade during partial transmission failure produced non depolarizing neuromuscular blocking drugs in the cat. Clin. Exp. Pharmacol. \& Physiol. 3:545-555.

Colquhoun, D. F and Sheridan, R. E. (1978). The actions of tubocurarine at the frog neuromuscular junction. J. Physiol. 293:247-284.

Diane, L. and Humphrey, P. R. (1988). Nicotinic receptors of frog ganglia resemble pharmacologically those of 
E. S. Ajibola et al

skeletal muscle. J. Neurosci. 8(9):32583265.

Dwoskin, L. P. and Crooks, P. A. (2001). Competitive neuronal receptor antagonists a new direction for drug discovery. $J$. Pharmacol. Exp.Ther. 298:395-402.

Gallacci, M. and Oliveira, A. C. (1990). Mechanisms of hexamethonium induced titanic fade in the isolated rat muscle. Arch. Int. Pharmacodyn. Ther. 305: 111-122.

Gibb, A. J. and Marshall, I. G. (1984). Pre and post junctional effects of tubocurarine and other nicotinic antagonists during repetitive stimulation in the rat. J. Physiol (Lond) 361:275-297.

Gibb, A. J. and Marshall, I. G. (1986). Nicotinic antagonists produce different amount of tetanic fade in the isolated diaphragm of the rat. Br. J. Pharmacol. 89:619-624.

Imre, R., Katrina, M. R., Adrian, J. E. and Stanley, A. F. (1995). Interaction of decamethonium with hexamethonium or vecuronium. An isobolographic analysis. Anaesth,Analg. 81:768-772.

Lukas, R. J., Changeux, J. P., Le Novere N., Albuquerque, E.X., Balfour, D. J. K., Bertrand, D., Chiappinell, V. A., Clarke, P. B., Collins, A. C., Grady, S. R., Keller, K. J., Lindstrom, J. M., Marks, M. J., Quick, M., Taylor, P. W. and Wonnacott, S. (1999). International union of pharmacology.XX. Current status of the nomenclature for nicotinic acetylcholine receptors and their subunits. Pharmacol. Res. 51:397-401.

Magleby, K. L., Pallota, B. S., Terrar, D. A. (1981). The effect of (+) - tubocurarine on neuromuscular transmission during repetitive stimulation in rat, mouse, and frog. J. Physiol (Lond) 312:97-113.
Massachusetts institute of technology (1999). The compound action potential of the frog sciatic nerve. Quantitative physiology: Cells and Tissues.

Miguel F., Laura, O. M., Alexandrina, T. M., Gracia, L. and Paulo Correia-De-Sa, P. (2003). Blockade of neuronal facilitatory nicotinic receptors containing $\alpha 3 \beta 2$ subinits contribute to titanic fade in the rat isolated diaphragm. Synapses 49:77-88.

Paton, W. D. M and Zaimis, E. J. (1951). Paralysis of autonomic ganglia by methonium salts. $\mathrm{Br} . J$. Pharmacol. 6:155168.

Rang, H. P (1982). The action of ganglionic blocking drugs on the synaptic responses of rat submandibular ganglion cells. $\mathrm{Br} . J$. Pharmacol.75:151-168.

Rang, H. P and Rylett, R. J. (1984). The interaction between hexamethonium and tubocurarine on the rat neuromuscular junction. Br. J. Pharmacol. 81(3): 519-531.

Richard, J. M. and John, H. B. (1981). Effects of hexamethonium and decamethonium on end plate current parameters. Mol. Pharmacol. 19: 276-281.

Silva, H. M. V., Ambiel, C. R. and Alves-doprado W. (1999). The neuromuscular transmission fade (Wendesky inhibition) induced by L-arginine in neuromuscular preparation from rats. Gen. Pharmacol. 32:705-712.

Wen-Mei F. and Jiunn-Jiun L. (1997). Regulation of acetyl choline release by presynaptic nicotinic receptors at developing neuromuscular synapses. Mol. Pharmacol. 51:390-398.

Received: May 16, 2009

Accepted: November, 20, 2009 